\title{
Systemic inflammation in 222.841 healthy employed smokers and nonsmokers: white blood cell count and relationship to spirometry
}

\author{
José Antonio Fiz Fernández ${ }^{1 *}$, Josép Morera Prats ${ }^{1}$, José Vicente Monsonis Artero², Alberto Calvo Mora², \\ Anna Vazquez Fariñas ${ }^{3}$, Anna Espinal ${ }^{3}$ and José Antonio Gelpi Méndez ${ }^{2}$
}

\begin{abstract}
Background: Smoking has been linked to low-grade systemic inflammation, a known risk factor for disease. This state is reflected in elevated white blood cell (WBC) count.

Objective: We analyzed the relationship between WBC count and smoking in healthy men and women across several age ranges who underwent preventive medical check-ups in the workplace. We also analysed the relationship between smoking and lung function.
\end{abstract}

Methods: Cross-sectional descriptive study in 163459 men and 59382 women aged between 16 and 70 years. Data analysed were smoking status, WBC count, and spirometry readings.

Results: Total WBC showed higher counts in both male and female smokers, around 1000 to $1300 \mathrm{cell} / \mathrm{ml}$ ( $t$ test, $P<0.001)$. Forced expiratory volume in 1 second $\left(\mathrm{FEV}_{1} \%\right)$ was higher in nonsmokers for both sexes between 25 to 54 years ( $t$ test, $P<0.001$ ). Analysis of covariance showed a multiple variable effect of age, sex, smoking status, body mass index on WBC count. The relationship between WBC blood count and smoking status was confirmed after the sample was stratified for these variables. Smokers with airway obstruction measured by $\mathrm{FEV}_{1} \%$ were found to have higher WBC counts, in comparison to smokers with a normal $\mathrm{FEV}_{1} \%$ among similar age and $\mathrm{BMI}$ groups.

Conclusions: Smoking increases WBC count and affects lung function. The effects are evident across a wide age range, underlining the importance of initiating preventive measures as soon as an individual begins to smoke.

\section{Background}

Since the 1970s smoking has been linked to low-grade systemic inflammation as reflected in elevated white blood cell (WBC) count [1-3], a well-established predictor of such serious health events as myocardial infarction [4], cancer [5], and chronic obstructive pulmonary disease [6]. Experiments in animals have demonstrated that tobacco smoke promotes leukocyte transit from bone marrow to small pulmonary vessels and that the effect on alveolar walls favours the development of pulmonary emphysema [7]. However, WBC count is also influenced by a range of acute and chronic infectious and inflammatory processes that are difficult to screen

\footnotetext{
*Correspondence: jafiz@msn.com

${ }^{1}$ Hospital Universitari Germans Trias i Pujol, Servicio de Neumología, Planta 8. Carretera del Canyet s/n, Badalona, Barcelona 08916, Spain

Full list of author information is available at the end of the article
}

for in population studies [8,9]. We therefore sought to describe the behaviour of WBC count in subjects known to be free of health conditions that could affect the results of laboratory tests, in the interest of providing data that would be useful for comparison with studies of the effect of tobacco smoking in either healthy or diseased populations.

To that end we analysed data available for a healthy employed population of men and women in a wide age range. Health vigilance programmes in Spain require that individuals undergoing preventive medical checkups in the workplace be free of any acute condition. When a worker is found to have an acute illness or an exacerbation of a chronic condition, the examination is postponed until the person has recovered. Therefore, the worker is known to be healthy at the time blood samples are taken. Our hypothesis was that laboratory results for

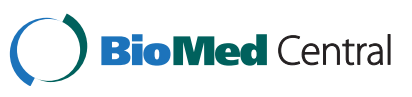

(c) 2012 Fiz et al.; licensee BioMed Central Ltd. This is an Open Access article distributed under the terms of the Creative Commons Attribution License (http://creativecommons.org/licenses/by/2.0), which permits unrestricted use, distribution, and reproduction in any medium, provided the original work is properly cited. 
Table 1 Anthropometric values of the population of healthy workers

\begin{tabular}{|c|c|c|c|c|c|c|}
\hline & \multicolumn{3}{|c|}{ Male } & \multicolumn{3}{|c|}{ Female } \\
\hline & Nonsmokers & Smokers & All & Nonsmokers & Smokers & All \\
\hline & $(n=78306)$ & $(n=85153)$ & $(n=163459$ & $(n=27883)$ & $(n=31499)$ & $(n=59382)$ \\
\hline Age (years) & $41.7(41.59-41.74)$ & $38.29(38.22-38.36)^{*}$ & 39.91 (39.85-39.96) & $40.84(40.71-40.96)$ & $36.70(36.60-36.80)^{*}$ & 38.64 (38.56-38.73) \\
\hline Weight (kg) & $82.6(82.48-82.67)$ & $80.94(80.95-81.04)^{*}$ & $81.78(81.66-81.79)$ & $64.71(64.57-64.85)$ & $63.41(63.28-63.54)^{*}$ & $64.02(63.92-64.12)$ \\
\hline Height (m) & 1.735 (1.735-1.736) & $1.742(1.741-1.742)$ & 1.739 (1.738-1.739) & $1.613(1.612-1.614)$ & $1.625(1.624-1.625)^{*}$ & $1.619(1.618-1.620)$ \\
\hline BMI $\left(\mathrm{kg} / \mathrm{m}^{2}\right)$ & $27.4(27.36-27.41)$ & $26.65(26.62-26.68)^{*}$ & 27.00 (26.98-27.02) & 24.89 (24.84-24.95) & $24.02(23.97-24.07)$ & $24.43(24.39-24.47)$ \\
\hline
\end{tabular}

Values are means and 95\% confidence intervals.

* Statistically significant differences between smokers and nonsmokers ( $t$ test for independent groups, $P<0.05$ ).

$B M I$ Body Mass Index.

this healthy working population would be less influenced by nonsmoking-related factors that might affect WBC count in a random population-based sample.

To confirm that smoking by itself leads to a state of sustained systemic inflammation, we conducted a crosssectional study of WBC count in healthy male and female smokers and nonsmokers across several age ranges who underwent preventive medical check-ups in the workplace, analysing the relationship between smoking and WBC count. Additionally, we sought to confirm a relationship between WBC count and declining lung function.

\section{Material and methods}

\section{Design and setting}

For this cross-sectional descriptive study we gathered clinical data from the 2009 records of Ibermutuamur Society for Preventive Medicine (Sociedad de Prevención de Ibermutuamur, Madrid). In 2009, this occupational health insurer covered 518587 workers in 29845 companies located throughout Spain. A total of 380353 individuals underwent a regularly scheduled health check-up as part of the insurer's vigilance programme.

\section{Study population}

Data for 163459 men and 59382 women, all white, between the ages of 16 and 70 years were examined between 1 January and 31 December 2009. This population sample, accounting for $58.6 \%$ of the insured workers attending the preventive medical check-up that year, met all the requirements for inclusion. Thus, morning blood samples were taken from workers who had fasted for at least 12 hours and who had been told not to smoke before the check-up. Subjects were allowed to have taken any prescribed medications with water.

\section{Data collection and variables}

An exhaustive medical history included the variables of interest for this study: smoking status (current smoker or nonsmoker), WBC count in peripheral blood (cells $/ \mathrm{ml}$ ), and spirometry readings (forced vital capacity [FVC], forced expiratory volume in 1 second $\left[\mathrm{FEV}_{1}\right]$, and the ratio of $\mathrm{FEV}_{1}$ to $\mathrm{FVC}$ ). The data belong to the health vigilance programme of the insurer, which is responsible for safe storage.

Other variables on record were anthropometric data (weight, height, body mass index [BMI] calculated as $\mathrm{kg} / \mathrm{m}^{2}$ ). To calculate BMI weight and height were measured (SECA-711 220, Class III scale; Medizinische Waagen und Messsysteme, Hamburg, Germany) with the worker wearing light clothing and no shoes. To reduce clothing weight further, objects were removed from pockets and belts and other accessories were taken off. These measurements were taken in the morning after urination and fasting.

Table 2 BMI for healthy workers

\begin{tabular}{|c|c|c|c|c|}
\hline \multirow{3}{*}{ Age (years) } & \multicolumn{2}{|c|}{ Male } & \multicolumn{2}{|c|}{ Female } \\
\hline & Nonsmokers & Smokers & Nonsmokers & Smokers \\
\hline & $(n=78306)$ & $(n=85153)$ & $(n=27883)$ & $(n=31499)$ \\
\hline $16-24$ & $24.85(24.73-24.97)^{*}$ & $24.23(24.14-24.33)$ & $22.99(22.79-23.20)$ & $22.86(22.70-23.02)$ \\
\hline $25-34$ & $26.30(26.24-26.35)^{*}$ & $26.02(25.97-26.07)$ & $23.54(23.45-23.64)$ & $23.34(23.26-23.41)$ \\
\hline $35-44$ & $27.43(27.38-27.48)^{*}$ & $27.11(27.06-27.16)$ & $24.71(24.61-24.81)^{*}$ & $24.21(24.13-24.30)$ \\
\hline $45-54$ & $28.21(28.16-28.26)^{*}$ & $27.53(27.47-27.60)$ & $25.89(25.79-25.99)^{*}$ & $25.23(25.12-25.34)$ \\
\hline $55-64$ & $28.55(28.48-28.62)^{*}$ & 27.68 (27.58-27.78) & $26.90(26.74-27.05)^{*}$ & $25.83(25.59-26.03)$ \\
\hline$>64$ & $28.23(27.83-28.62)$ & $27.72(27.02-28.42)$ & $26.78(26.08-27.49)$ & 24.69 (21.44-27.93) \\
\hline
\end{tabular}

Values are means and 95\% confidence intervals.

* Statistically significant differences between smokers and nonsmokers, for both males and females ( $t$ test for independent groups, $P<0.001)$.

BMI: Body Mass Index $\left(\mathrm{kg} / \mathrm{m}^{2}\right)$. n: Subjects number. 
Table 3 White blood cell counts (cells/ml) for healthy workers

\begin{tabular}{|c|c|c|c|c|c|c|}
\hline \multirow{3}{*}{$\begin{array}{l}\text { Age } \\
\text { (years) }\end{array}$} & \multicolumn{3}{|c|}{ Male } & \multicolumn{3}{|c|}{ Female } \\
\hline & Nonsmokers & Smokers & All & Nonsmokers & Smokers & All \\
\hline & $(n=78306)$ & $(n=85153)$ & $(n=163459)$ & $(n=27883)$ & $(n=31499)$ & $(n=59382)$ \\
\hline $16-24$ & $6555(6509-6601)^{*}$ & 7296 (7253-7339) & $7010(6978-7042) 1$ & $6771(6681-6861)^{*}$ & 7391 (7317-7466) & 7168 (7109-7226) \\
\hline $25-34$ & $6456(6434-6437)^{*}$ & 7569 (7546-7592) & 7118 (7100-7135) & $6523(6485-6561)^{*}$ & $7292(7257-7327)$ & 6995 (6968-7021) \\
\hline $35-44$ & $6436(6416-6455)^{*}$ & 7927 (7902-7953) & $7244(7226-7261)$ & $6368(6333-6404)^{*}$ & 7441 (7401-7480) & $6973(6944-7001)$ \\
\hline $45-54$ & $6512(6491-6532)^{*}$ & $8124(8092-8155)$ & 7245 (7225-7265) & $6164(6132-6196)^{*}$ & 7421 (7372-7471) & 6699 (6670-6729) \\
\hline $55-64$ & $6600(6572-6629)^{*}$ & 7914 (7864-7965) & 7076 (7048-7103) & $5989(5939-6040)^{*}$ & 7235 (7126-7343) & $6313(6264-6363)$ \\
\hline$>64$ & $6518(6358-6680)$ & 7410 (7132-7688) & 6744 (6600-6888) & $5987(5677-6296)$ & $6821(5489-8153)$ & $6058(5758-6359)$ \\
\hline
\end{tabular}

Values are means and $95 \%$ confidence intervals.

* Statistically significant differences between smokers and nonsmokers, for both males and females ( $t$ test for independent groups, $P<0.001$ ).

$\mathrm{n}$ : Subject number.

The scale was checked and calibrated periodically by an independent company (Reimedical, SL; Madrid, Spain).

For spirometry, examiners used a Spirolab II RS232 device (Medical International Research, Rome, Italy) as part of the routine check-up. To ensure quality of measurements, the equipment was inspected by the health insurer's staff and calibrated by an independent company, following

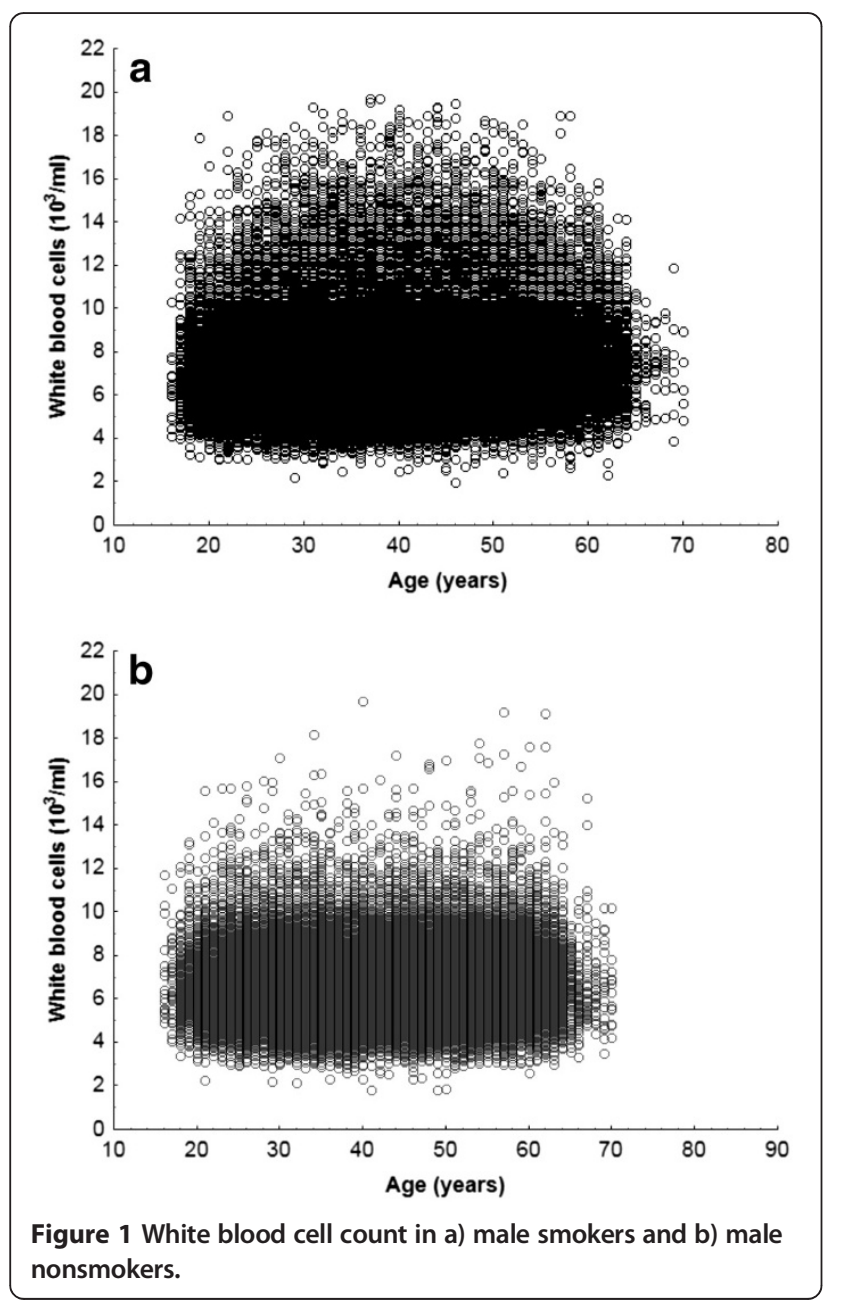

the guidelines of the Spanish Society of Pulmonology and Thoracic Surgery (SEPAR) [10]. The worker was encouraged by the examiner to take a deep breath and then exhale as forcefully as possible. The highest values for FVC and $\mathrm{FEV}_{1}$ were recorded. The results were compared with reference values for a Spanish population, using the most recently updated tables [11].
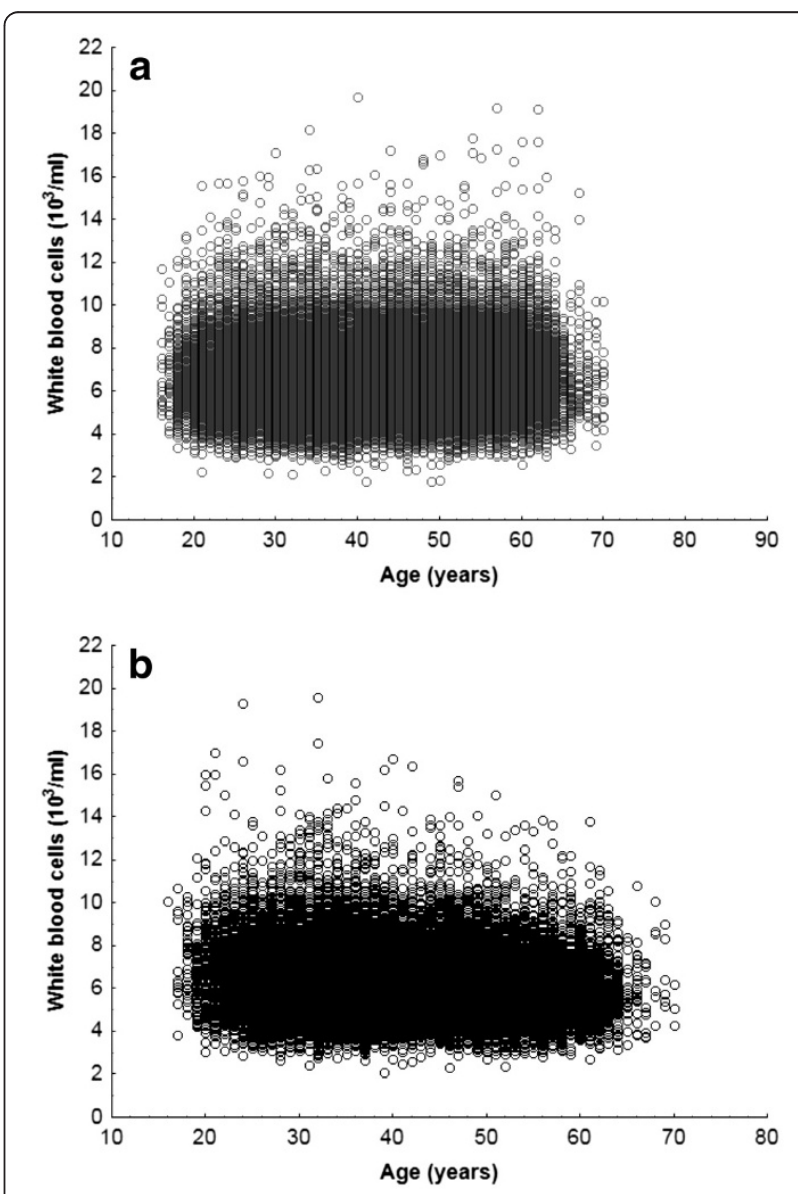

Figure 2 White blood cell count in a) female smokers and b) female nonsmokers. 
All blood samples were analysed by the same laboratory (Megalab, SA, Madrid) using the same automated cell counter (Cell-Dyn Sapphire, Abbott Laboratories, Abbott Park, IL, USA).

\section{Statistical analysis}

After verifying normality of distribution, we subjected the data set to $t$ test analysis or variance analysis (ANOVA) to compare differences between groups, followed by analysis of covariance (ANCOVA) to find confounding variables. Medians were compared using nonparametric tests as appropriate for the variable. Smokers and nonsmokers were compared by sex and by age and BMI strata. Results of ANOVA were expressed as mean (SD) and 95\% confidence interval (CI); results of ANCOVA were expressed as mean (SEM). $P$ values less than 0.05 were considered statistically significant. Statistics were compiled and analysed with GraphPad Quick Calcs software (San Diego, CA, USA).

\section{Results}

The characteristics of the population of 163459 men and 59382 women are shown in Table 1, by smoking habit. The mean (SD) age was 39.6 (10.6) years, with significant differences between smokers and nosmokers $(P<0.05)$. Among males the BMI of non smokers was statistically higher than that of smokers (by less than $1 \mathrm{~kg} / \mathrm{m} 3$ ) among all age groups, while among females, BMI was statistically higher among non smokers (by less than $1 \mathrm{~kg} / \mathrm{m} 3$ ) (Table 2).

Total WBC counts were higher in smokers of both sexes by around 1180 cells/ml (ANOVA, $P<0.001 ; t$ test for independent data, $P<0.001)$. ANOVA confirmed age (in six ranges) and smoking (in two categories) as independently associated with WBC count in men and women (Table 3). Men have around 1000 cells $/ \mathrm{ml}$ more than women. Scatterplots of the point distribution of WBC counts for the population show that higher counts were found in male and female smokers (Figures 1 and 2).

The analysis of spirometric findings by smoking status, age and sex showed that $\mathrm{FEV}_{1} \%$ (Forced expiratory volume in one second in percentage respect to normal values) was higher in male nonsmokers from the age of 25 years onward and in female nonsmokers in the range of ages from 25 years to 54 years (Table 4). The findings were similar for the $\mathrm{FEV}_{1} / \mathrm{FVC}$ ratio and $\mathrm{FVC} \%$ (Forced vital capacity expressed as a percentage respect to normal values) (Table 5).

Table 4 Forced expiratory volume in 1 second $\left(\mathrm{FEV}_{\mathbf{1}}\right.$ and $\left.\mathrm{FEV}_{\mathbf{1}} \%\right)$ in active workers

\begin{tabular}{|c|c|c|c|c|}
\hline \multirow{3}{*}{$\begin{array}{l}\text { Age } \\
\text { (years) }\end{array}$} & \multicolumn{2}{|c|}{ Male } & \multicolumn{2}{|c|}{ Female } \\
\hline & Nonsmokers & Smokers & Nonsmokers & Smokers \\
\hline & $(n=78306)$ & $(n=85153)$ & $(n=27883)$ & $(n=31499)$ \\
\hline \multicolumn{5}{|l|}{$16-24$} \\
\hline $\mathrm{FEV}_{1}(\mathrm{I})$ & $4.245(4.225-4.265)$ & $4.219(4.203-4.234)$ & $3.075(3.050-3.100)$ & $3.083(3.065-3.101)$ \\
\hline $\mathrm{FEV}_{1} \%$ & 98.5 (98.1-98.9) & 98.3 (98.0-98.6) & $94.3(93.6-94.9)$ & $94.6(94.1-95.1)$ \\
\hline \multicolumn{5}{|l|}{$25-34$} \\
\hline $\mathrm{FEV}_{1}(\mathrm{I})$ & $4.170(4.160-4.1807)$ & $4.140(4.132-4.148)$ & $3.073(3.063-3.084)$ & $3.067(3.060-3.075)$ \\
\hline $\mathrm{FEV}_{1} \%$ & $100.4(100.2-100.6)^{*}$ & $99.3(99.1-99.5)$ & $98.6(98.3-98.9)^{*}$ & $97.8(97.5-97.9)$ \\
\hline \multicolumn{5}{|l|}{$35-44$} \\
\hline $\mathrm{FEV}_{1}(\mathrm{I})$ & $3.936(3.928-3.945)$ & $3.832(3.824-3.839)$ & $2.918(2.908-2.929)$ & $2.861(2.851-2.870)$ \\
\hline $\mathrm{FEV}_{1} \%$ & $102.3(102.1-102.5)^{*}$ & 99.4 (99.2-99.6) & $102.6(102.2-102.9)^{*}$ & $100.1(99.8-100.4)$ \\
\hline \multicolumn{5}{|l|}{$45-54$} \\
\hline $\mathrm{FEV}_{1}(\mathrm{I})$ & $3.588(3.580-3.596)$ & 3.388 (3.379-3.397) & $2.630(2.620-2.639)$ & $2.536(2.525-2.548)$ \\
\hline $\mathrm{FEV}_{1} \%$ & $102.6(102.3-102.8)^{*}$ & $97.0(96.7-97.2)$ & $103.9(103.5-104.2)^{*}$ & 98.7 (98.3-99.1) \\
\hline \multicolumn{5}{|l|}{$55-64$} \\
\hline $\mathrm{FEV}_{1}(\mathrm{I})$ & $3.142(3.131-3.153)^{*}$ & $2.917(2.901-2.932)$ & $2.305(2.290-2.320)$ & $2.219(2.186-2.239)$ \\
\hline $\mathrm{FEV}_{1} \%$ & 100.8 (100.4-101.1) & 93.5 (93.0-93.9) & $103.6(103.0-104.2)$ & 98.6 (97.5-99.8) \\
\hline \multicolumn{5}{|l|}{$>64$} \\
\hline FEV $_{1}(\mathrm{I})$ & $2.887(2.825-2.949)$ & $2.576(2.475-2.677)$ & $2.051(1.955-2.14)$ & $1.851(1.538-2.163)$ \\
\hline $\mathrm{FEV}_{1} \%$ & $98.9(97.7-100.8)^{*}$ & $90.3(86.8-93.7)$ & 104.5 (99.9-109) & 86.5 (79.1-93.9) \\
\hline
\end{tabular}

Values are means and $95 \%$ confidence intervals.

* Statistically significant differences in $\mathrm{FEV}_{1} \%$ between smokers and nonsmokers for males and females ( $t$ test for independent groups, $P<0.001$ ).

$\mathrm{FEV}_{1}(\mathrm{l})$ : Forced expiratory volume in 1 second in liters.

$\mathrm{FEV}_{1} \%$ : Forced expiratory volume in one second in percentage respect to normal values. 
Table 5 Forced vital capacity (FVC) and FVC\% and the ratio FEV $_{1}$ to FVC (FEV $/$ FVC\%) in healthy active workers

\begin{tabular}{|c|c|c|c|c|}
\hline \multirow[b]{2}{*}{ Age (years) } & \multicolumn{2}{|c|}{ Males } & \multicolumn{2}{|c|}{ Females } \\
\hline & Nonsmokers $(n=78$ 306) & Smokers $(n=85153)$ & Nonsmokers ( $\mathrm{n}=27883$ ) & Smokers $(n=31499)$ \\
\hline \multicolumn{5}{|l|}{$16-24$} \\
\hline $\mathrm{FEV}_{1} / \mathrm{FVC} \%$ & $86.9(86.7-87.2)^{*}$ & $86.2(86.0-86.4)$ & $88.0(87.6-88.5)^{*}$ & $86.9(86.7-87.3)$ \\
\hline FVC (I) & $4.907(4.885-4.930)$ & $4.920(4.902-4.937)$ & $3.520(3.481-3.538)$ & $3.560(3.539-3.581)$ \\
\hline FVC\% & $96.0(95.6-96.4)^{*}$ & $96.9(96.6-97.3)$ & $93.4(92.7-94.0)$ & $94.8(94.3-95.3)$ \\
\hline \multicolumn{5}{|l|}{$25-34$} \\
\hline $\mathrm{FEV}_{1} / \mathrm{FVC} \%$ & $86.0(85.9-86.1)^{*}$ & $85.3(85.2-85.4)$ & $87.2(87.1-87.4)^{*}$ & $86.4(86.3-86.6)$ \\
\hline FVC (I) & $4.873(4.864-4.884)$ & 4.875 (4.865-4.883) & 3.540 (3.527-3.553) & 3.563 (3.553-3.573) \\
\hline FVC\% & $97.4(97.7-98.0)$ & $97.7(97.6-97.9)$ & $98.1(97.8-98.4$ & $98.3(98.0-98.5)$ \\
\hline \multicolumn{5}{|l|}{$35-44$} \\
\hline $\mathrm{FEV}_{1} / \mathrm{FVC} \%$ & $85.6(85.5-85.7)^{*}$ & $84.5(84.4-84.6)$ & $86.3(86.1-86.5)^{*}$ & $85.1(84.9-85.2)$ \\
\hline FVC (I) & $4.623(4.613-4.633)$ & $4.556(4.547-4.565)$ & $3.399(3.386-3.412)$ & $3.378(3.367-3.389)$ \\
\hline FVC\% & $98.8(98.7-99.0)^{*}$ & $97.4(97.2-97.6)$ & $102.2(101.8-102.5)$ & $101.4(101.1-101.7)$ \\
\hline \multicolumn{5}{|l|}{$45-54$} \\
\hline $\mathrm{FEV}_{1} / \mathrm{FVC}^{2} \%$ & $85.3(85.2-85.4)^{*}$ & $83.2(83.1-83.3)$ & $85.9(85.8-86.1)^{*}$ & $83.9(83.7-84.1)$ \\
\hline FVC(I) & $4.224(4.214-4.233)$ & $4.088(4.077-4.099)$ & $3.075(3.063-3.087)$ & $3.036(3.022-3.049)$ \\
\hline FVC\% & $97.7(97.5-97.9)^{*}$ & $94.9(94.7-95.1)$ & $102.8(102.5-103.2)^{*}$ & $100.2(99.7-100.6)$ \\
\hline \multicolumn{5}{|l|}{$55-64$} \\
\hline $\mathrm{FEV}_{1} / \mathrm{FVC} \%$ & $84.2(84.1-84.4)^{*}$ & $81.6(81.3-81.8)$ & $85.5(85.2-85.8)^{*}$ & $83.7(83.2-84.2)$ \\
\hline FVC (I) & 3.746 (3.733-3.759) & 3.588 (3.570-3.605) & $2.710(2.692-2.729)$ & $2.654(2.623-2.685)$ \\
\hline FVC\% & $95.6(95.3-95.9)^{*}$ & $91.6(91.2-92.0)$ & $101.8(101.2-102.5)^{*}$ & $98.9(97.8-100.0)$ \\
\hline \multicolumn{5}{|l|}{$>64$} \\
\hline $\mathrm{FEV}_{1} / \mathrm{FVC} \%$ & $83.4(82.5-84.3)^{*}$ & $80.2(78.3-82.2)$ & $85.8(84.0-87.6)$ & 79.4 (71.8-86.9) \\
\hline FVC (I) & $3.230(3.112-3.350)$ & $3.480(3.405-3.554)$ & $2.396(2.293-2.499)$ & $2.350(1.955-2.744)$ \\
\hline FVC\% & 88.9 (85.6-92.2) & $92.9(91.2-94.6)$ & $101.2(97.2-105.1)$ & 86.7 (79.9-93.6) \\
\hline
\end{tabular}

Values are means and 95\% confidence intervals.

* Statistically significant differences between smokers and nonsmokers for males and females ( $t$ test for independent groups, with $P<0.001$ ).

FVC(I):Forced vital capacity in liters.

FVC(\%):Forced vital capacity expressed as a percentage respect to normal values..

$\mathrm{FEV}_{1}$ : Forced volume in 1 second in liters.

$\mathrm{FEV}_{1} / \mathrm{FVC} \%$ : The ratio of $F E V_{1}$ to $F V C$ expressed as a percentage.

When presence of bronchial obstruction reflected by $\mathrm{FEV}_{1} \%$ was compared between age ranges, sexes, BMI ranges, and WBC count, we detected significant differences for male smokers between the ages of 35 and 64 years, regardless of BMI, and for female smokers with a BMI $<30$ between the ages of 44 and 54 years (Table 6).

ANCOVA confirmed the effect of age, sex, smoking and BMI on $\log (\mathrm{WBC})$ count demonstrating that the weight of the variable smoking was greater than all the other variables. In the established model for the logarithm of WBC count were included the set of covariates given by smoking, sex, BMI and age. All variables were statistically significant. About smoking, smokers have statistically higher levels of WBC than not smokers (estimated coeff $=0.176$, $\mathrm{SE}=0.001$ ). Abou sex, males have statistically higher levels of WBC than females (estimated coeff $=0.022, \mathrm{SE}=0.001$ ).
For quantitative covariates, BMI and age, the results obtained from the estimated model were: BMI-estimated coeff $=0.0001(\mathrm{SE}=0.00005)$ and age-estimated $\operatorname{coeff}=$ 8.494 $(\mathrm{SE}=0.003)$.

\section{Discussion}

This study provides clear confirmation that WBC count rises with smoking, even in a healthy, employed population. The count was higher in smokers by $1000-1300$ cells $/ \mathrm{ml}$ across a broad range of ages for both men and women and across a broader span of ages for men. Spirometric markers of lung function were also lower in healthy smokers.

The relation between smoking and WBC count has been reported previously [4,12-15]. Zalokar and colleagues [4], on studying more than 7000 men employed in public administration in Paris, found that a higher percentage of 
Table 6 White blood cell count (cells/ml) and $\mathrm{FEV}_{\mathbf{1}} \%$ in smokers

\begin{tabular}{|c|c|c|c|c|c|c|c|}
\hline \multirow[b]{2}{*}{ Age (years) } & \multirow[b]{2}{*}{ FEV $_{1}(\%)$} & \multicolumn{3}{|c|}{ Male smokers } & \multicolumn{3}{|c|}{ Female smokers } \\
\hline & & $\mathrm{BMI} \geq 30$ & $25 \leq \mathrm{BMI}<30$ & BMI $<25$ & $\mathrm{BMI} \geq \mathbf{3 0}$ & $25 \leq \mathrm{BMI}<30$ & BMI $<25$ \\
\hline \multirow[t]{3}{*}{$16-24$} & $\geq 80$ & 7595(1824) & 7072(1735) & 6895(1746) & 8121(1978) & 7458(1849) & 7024(1887) \\
\hline & $\geq \mathbf{5 0}<\mathbf{8 0}$ & $9102(2281)$ & 7855(1992) & $6649(1967)$ & $10300(-)$ & $8764(2128)$ & $7128(1780)$ \\
\hline & $<50$ & - & $7400(-)$ & 7430 (395) & $5650(-)$ & - & 7517 (4931) \\
\hline \multirow[t]{3}{*}{$25-34$} & $\geq \mathbf{8 0}$ & 7623(1873) & 7136(1848) & 6923(1852) & $8014(1967)$ & 7252(1887) & 6821(1819) \\
\hline & $\geq \mathbf{5 0}<\mathbf{8 0}$ & 8124(1876) & 7543(1889) & 6988(2237 ) & 7701(1810) & 7447(1619) & $7142(1959)$ \\
\hline & $<50$ & $9615(2211)$ & 7096(1596) & $7300(2937)$ & $8367(1760)$ & 8050(1906) & 7538(1922) \\
\hline \multirow[t]{3}{*}{$35-44$} & $\geq \mathbf{8 0}$ & 7595(1944) & 7188(1954) & 7083(2094) & 7732(1999) & 7138(1867) & 6778(1876) \\
\hline & $\geq 50<80$ & $8216(2208) *$ & 7613(1925) & $7768(2468) *$ & 7819(1723) & 6926(1780) & $7284(2321)$ \\
\hline & $<50$ & 7965(1497) & 7993(2102) & $9589(3245)$ & $9480(1584)$ & $6250(540)$ & $7772(2286)$ \\
\hline \multirow[t]{3}{*}{$45-54$} & $\geq 80$ & 7386(1859) & 7134(1955) & $7265(2168)$ & $7108(1800)$ & $6747(1785)$ & 6530(1798) \\
\hline & $\geq 50<80$ & $8240(2161) *$ & $7872(2090)$ * & $8602(2419)$ * & $8042(2080)$ & $7696(1724) *$ & $7682(1867)$ * \\
\hline & $<50$ & $7912(2120)$ & $8269(2255)$ & 8333(2508) & $8258(1756)$ & $7696(2236)$ & 6831(1090) \\
\hline \multirow[t]{3}{*}{$55-64$} & $\geq 80$ & $7141(1732)$ & 6983(1815) & 7087(1984) & 6646(1671) & 6305(1551) & 6139(1616) \\
\hline & $\geq 50<80$ & $8031(2150) *$ & $7736(8042) *$ & $7720(1853) *$ & $6607(1505)$ & 7462(2085) & $6781(2393)$ \\
\hline & $<50$ & 7649(1779) & 7704(1687) & 8291(1937) & $5863(1244)$ & 6192(1922) & $6598(1642)$ \\
\hline
\end{tabular}

Values are means (SD).

${ }^{*}$ Median test for white blood cell count in male and female smokers. Comparisons are between three levels of airway obstruction reflected by $\mathrm{FEV} \mathrm{V}_{1} \%$. $(\mathrm{P}<0.001)$ BMI: Body mass index $\left(\mathrm{kg} / \mathrm{m}^{2}\right)$.

$\mathrm{FEV}_{1}(\%)$ : Forced vital capacity expressed as a percentage respect to normal value.

smokers had WBC counts over 6800 cells $/ \mathrm{ml}$. More recently, Smith and colleagues [12] demonstrated higher counts in a sample of 6902 male and 8405 female smokers. Elevated WBC counts play a role in processes that lead to cardiovascular diseases and increased risk of death. In one recent cohort study, mortality was higher in relation to a WBC count over 6000 cells/ml [13]. In an early prospective cohort study in which subjects were followed for 6.5 years, Friedman and colleagues $[14,15]$ showed that smoking was associated with higher rates of myocardial infarcts and that WBC counts were much higher in smokers.

Age is also associated with WBC count. Although it was recently claimed that this marker decreases with age [13], we found that older male smokers had higher WBC counts, while levels in nonsmokers remained stable (Table 3), a finding that is consistent with a widely reported dose-response effect of smoking [4,16-22]. The observation of a lower WBC count in smokers who quit also points to the relevance of dose on effect. Roethig and colleagues [23] recently reported that WBC count decreased within the first three days of abstinence and that lower counts were sustained after a year of follow-up of former smokers. At five years, WBC counts approximated those of nonsmokers. In differential cell counts, elevated subpopulations of granulocytes and lymphocytes have also been observed in smokers [12,23-25]. However, it is important to note that BMI also affects WBC count, with obesity creating a proinflammatory state characterized by increases in $C$ reactive protein and interleukin 6 concentrations as well as in WBC count
[26,27]. In our study, ANCOVA identified BMI as a covariant of WBC count, as smokers in higher BMI strata were found to have elevated counts regardless of sex or lung function. Within age ranges, however, male smokers who had developed airflow limitation had still higher counts.

BMI and smoking have an inverse relationship [28]. Recently, Kauffman et al. showed that this relationship is moderated by sedentary conduct [29]. BMI was higher in larger sedentary compared to lower sedentary smokers. In our work, while BMI was statistically significant, this difference was not clinically significant The health benefit of being a nosmoker possibly outways by far the extra risk that less than a $1 \mathrm{~kg} / \mathrm{m}^{2}$ increase in BMI.

Finally, our study also demonstrated lower spirometric variables $\left(\mathrm{FEV}_{1} \%\right.$ and $\left.\mathrm{FEV}_{1} / \mathrm{FVC} \%\right)$ in smokers and that WBC counts were more sharply elevated in smokers with evident airflow limitation. This association between the development of bronchial obstruction and the degree of systemic inflammation reflected by total WBC count is clinically significant and consistent with the findings of Gan and colleagues [30,31]. These authors studied more than 7000 adults ( $>40$ years of age) during a national nutritional study that collected data on several markers of inflammation, observing that counts and concentrations were high in smokers and that elevation was related to $\mathrm{FEV}_{1} \%$. Such findings, like ours, indicate that the effects of smoking clearly extend beyond the well-known repercussions on the respiratory system to include low-grade systemic inflammation, a known risk 
factor for health conditions that increase risk of mortality such as arterial sclerosis, heart failure, and reduced cerebral blood flow. That we found that even the young smokers in our study were affected underlines the importance of initiating preventive measures as soon as an individual acquires the smoking habit.

The study's main limitation was the unavailability of information about smoking duration and dose (packetyears), which would have given us greater understanding of the dose-response effect of smoking on WBC count. On the other hand, the study's strength resides in its large sample size and an extensive age range.

In summary, this study in a healthy population undergoing a routine workplace check-up provides direct evidence of the proinflammatory effect of smoking, specifically elevated WBC counts. The link between smoking and elevated WBC count persisted even after stratification of the sample for age, sex, and BMI, which were also independent predictors. Finally, in this healthy population we observed a close tie between the development of airflow limitation and smoking. Although this study has provided clear evidence of a proinflammatory effect of smoking that begins early in healthy smokers, the cross-sectional design does not allow us to provide incidence rates that would indicate when disease processes begin to develop.

This research has been partially supported by a grant (MTM2009-10893) from the Ministry of Education of Spain.

\section{Competing interests}

The authors declare that they have no competing interests.

\section{Author details}

${ }^{1}$ Hospital Universitari Germans Trias i Pujol, Servicio de Neumología, Planta 8. Carretera del Canyet s/n, Badalona, Barcelona 08916, Spain. ${ }^{2}$ Sociedad de Prevención de Ibermutuamur, Argos 4-6, Madrid 28037, Spain. ${ }^{3}$ Servei d'statística Aplicada, Universitat Autónoma de Barcelona, Bellaterra (Cerdanyola del valles) 08193, Spain.

\section{Authors' contributions}

JAFF, JMP, JVMA, ACM, AVF, AE, and JAGM participated in the elaboration and analysis of the data, as well as in the writing of the present manuscript. All authors have read and approved the final manuscript.

Received: 5 December 2011 Accepted: 29 March 2012

Published: 21 May 2012

\section{References}

1. Yeung MC, Buncio AD: Leukocyte count, smoking, and lung function. Am J Med 1984, 76:31-37.

2. Friedman GD, Siegelaub AB, Seltzer CC, Feldman R, Collen MF: Smoking habits and the leukocyte count. Arch Environ Health 1974, 29:26-137.

3. Tell GS, Grimm RH, Vellar OD, Theodorsen L: The relationship of white cell count, platelet count, and hematocrit to cigarette smoking in adolescents: the Oslo Youth Study. Circulation 1985, 72:971-974.

4. Zalokar JB, Richard JL, Claude JR, Pharm D: Leukocyte count, smoking, and myocardial infarction. N Engl J Med 1981, 304:465-468.

5. Lampe JW, Stepnaniants SB, Mao M, Radich JP, Dai H, Linsley PS, Friend SH, Potter JD: Signatures of environmental exposures using peripheral leukocyte gene expression: Tobacco smoke. Cancer Epidemiol Biomarkers Prev 2004, 13:445-453.
6. Cosio MG, Saetta M, Agusti A: Immunologic aspects of chronic obstructive pulmonary disease. N Engl J Med 2009, 360:2445-2454

7. Terashima T, Klut ME, English D, Hards J, Hogg JC, van Eeden St F: Cigarette smoking causes sequestration of polymorphonuclear leukocytes released from the bone marrow in lung microvessels. Am J Respir Cell Mol Biol 1999, 20:171-177.

8. Adams DH, Lloyd AR: Chemokines: leucocyte recruitment and activation cytokines. Lancet 1997, 349:490-495.

9. Arcavi L, Benowitz NL: Cigarette smoking and infection. Arch Intern Med 2004, 164:2206-2216.

10. Casan P, Burgos F, Barberá JA, Giner J: Espirometría. In Manual de procedimientos SEPAR. Sociedad Española de Neumología y Cirugía Torácica. Edited by SEPAR. Madrid: S.A de Ediciones; 2002:4-15.

11. Castellsagué J, Burgos F, Sunyer J, Barberà JA, Roca J, for the Barcelona Collaborative Group on Reference: Values for Pulmonary Function testing and the Spanish Group of the European Community Respiratory health Survey. Respir Med 1998, 92:401-407.

12. Smith MR, Kinmonth AL, Lubel RN, Bingham S, Day NE, Wareham NJ, Welch A, Khaw KT: Smoking status and differential white cell count in men and women in the EPIC-Norfolk population. Atherosclerosis 2003, 169:331-337.

13. Ruggiero C, Metter EJ, Cherubini A, Maggio M, Sen R, Najjar SS, Windham GB, Ble A, Senin U, Ferrucci L: White blood cell count and mortality in the Baltimore longitudinal study of aging. J Am Coll Cardiol 2007, 49:1842-1850.

14. Friedman GD, Klatsky AL, Siegelaub AB: The leukocyte count as a predictor of myocardial infarction. N Engl J Med 1974, 290:1275-1278.

15. Friedman GD, Siegelaub AB, Seltzer CC, Feldman R, Collen MF: Smoking habits and the leukocyte count. Arch Environ Health 1973, 26:137-143.

16. Roethig HJ, Feng S, Liang Q, Liu J, Rees WA, Zedler BK: A 12-month, randomized, controlled study to evaluate exposure and cardiovascular risk factors in adult smokers switching from conventional cigarettes to a second generation electrically heated cigarette smoking system. J Clin Pharmacol 2008, 48:580-591.

17. Phillips AN, Neaton JD, Cook DG, Grimm RH, Shaper AG: Leukocyte count and risk of major coronary heart disease events. Am J Epidemiol 1992, 136:376-380.

18. Schwartz J, Weiss ST: Host and environmental factors influencing the peripheral blood leukocyte count. Am J Epidemiol 1991, 134:1402-1409.

19. Nieto FJ, Szklo M, Folsom AR, Rock R, Mercuri M: Leukocyte count correlates in midle-aged adults: the atherosclerosis risk in communities (ARIC) study. Am J Epidemiol 1992, 136:525-537.

20. Yarnell JW, Sweetnam PM, Rogers S, Elwood PC, Bainton D, Baker IA, et al: Some long term effects of smoking on the haemostatic system: a report from the Caerphilly and Speedwell collaborative surveys. J Clin Pathol 1987, 40:909-913.

21. Hansen LK, Grimm RH, Neaton JD: The relationship of white blood cell count to other cardiovascular risk factors. Int J Epidemiol 1990, 19:881-888.

22. Petitti DB, Kipp H: The leukocyte count: associations with intensity of smoking and persistence of effect after quitting. Am J Epidemiol 1986, 123:89-95.

23. Roethig AJ, Koval T, Muhammad-Kah R, Jin $Y$, Mendes $P$, Unverdorben $M$ Short term effects of reduced exposure to cigarette smoke on white blood cells, platelets and red blood cells in adult cigarette smokers. Regul Toxicol Pharmacol 2010, 57:333-337.

24. Al-Awadhi AM, Alfadhli SM, Mustafa NY, Sharma PN: Effects of cigarette smoking on hematological parameters and von Willebrand factor functional activity levels in asymptomatic male and female Arab smokers. Med Princ Pract 2008, 17:149-153.

25. Tanigawa H, Iso K, Yamagishi I, Muraki N, Kawamura A, Nakata S, Sakurai T, Ohira T, Shimamoto T: Association of lymphocyte sub-populations with clustered features of metabolic syndrome in middle-aged Japanese men. Atherosclerosis 2004, 173:295-300.

26. Bastard JP, Maachi M, Lagathu C, et al: Recent advances in the relationship between obesity, inflammation, and insulin resistance. Eur Cytokine Netw 2006, 17:4-12.

27. Huang Z-S, Chien KL, Yang CY, Tsai KS, Wang CH: Peripheral differential leukocyte counts in humans vary with hyperlipidemia, smoking and body mass index. Lipids 2001, 36:237-245.

28. Albanes D, Jones YD, Micozzi MS, Mattson ME: Associations between smoking and body weight in the US population: analysis of NHANES II. Am J Public Health 1987, 77:439-444.

29. Kauffman A, Augustson EM, Patrick H: Unraveling the relationship between smoking and weight: The role of sedentary behavior. J Obes in press. 
30. Qi Gan W, Man P, Sin DD: The interactions between cigarette smoking and reduced lung function on systemic inflammation. Chest 2005, 127:558-564.

31. Qi Gan W, Man P, Senthilselvan A, Sin D: Association between chronic obstructive pulmonary disease and systemic inflammation: a systematic review and a meta-analysis. Thorax 2004, 59:574-580.

doi:10.1186/1617-9625-10-7

Cite this article as: Fiz et al:: Systemic inflammation in 222.841 healthy employed smokers and nonsmokers: white blood cell count and relationship to spirometry. Tobacco Induced Diseases 2012 10:7.

\section{Submit your next manuscript to BioMed Central and take full advantage of:}

- Convenient online submission

- Thorough peer review

- No space constraints or color figure charges

- Immediate publication on acceptance

- Inclusion in PubMed, CAS, Scopus and Google Scholar

- Research which is freely available for redistribution 